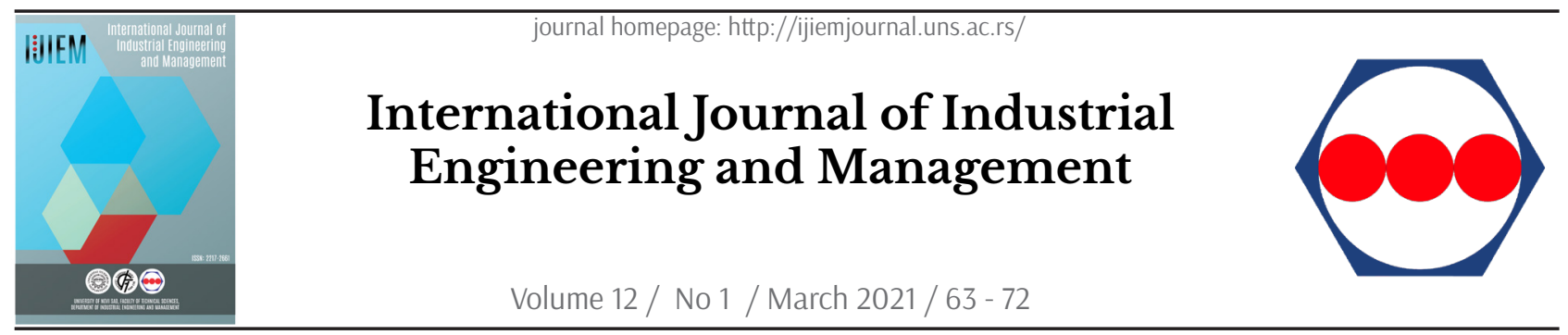

Original research article

\title{
The Impact of Government Measures on Business Development in the ICT sector
}

\author{
I. Bestvina Bukvić a*, I. Đurđević Babić ${ }^{b}$ \\ a Josip Juraj Strossmayer University of Osijek, Faculty of Economics, Osijek, Croatia; \\ b Josip Juraj Strossmayer University of Osijek, Faculty of Education, Osijek, Croatia
}

\begin{abstract}
A B STR A C T
The purpose of this paper is to identify which economic measures do ICT experts perceive as important for the development of the ICT sector and to explore whether there is a need to introduce special developmental measures depending on the international or domestic market orientation. To gain valuable results, a survey on 112 ICT experts was conducted and, along with descriptive statistics measures, a chi square test and association rules were used in the analysis. The results of the primary research indicate variables that need to be addressed in the development of new policies (primary reduction of bureaucratization, taxation and frequency of legal changes) and obviates the need for introducing separate policies for internationally oriented companies.
\end{abstract}

ARTICLE INFO

Article history:

Received November 12, 2020

Revised February 23, 2021

Accepted February 24, 2021

Published online March 4, 2021

Keywords:

Government policies;

ICT sector development;

International sales orientation

*Corresponding author:

Ivana Bestvina Bukvić

ibbukvic@unios.hr

\section{Introduction}

Digital transformation, the use of Information Communication Technologies (ICT) and the development of businesses in the ICT sector affect the increase of national competitiveness [1] and national innovation efficiency [2], growth of gross domestic product, decrease social income inequality [3,4], influence the increase of national innovations and economic growth [5], etc. This leads to the conclusion that this is a key sector for the 21 st century $[5,6]$ and therefore its development should be supported on a strategic level. Nations all over the world are investing efforts through different policies and measures to support the development of the ICT sector and by fostering digital transformation. One of 6 European Commission (EC) priorities is A Europe fit for a digital age whose aim is, among others, fostering digital transformation for the purpose of opening up new opportunities for businesses and enabling a vibrant and sustainable economy [7]. This leads to a necessity for conducting research in the field of efficiency analysis for ICT supporting economic measures, as it was found that their success depends on specific economic factors in every country $[8,9,10$, 11]. Following, the authors wanted to identify the government measures which are contributing to the Croatian ICT sector development by the opinion of ICT experts. Through literature review it was identified that there is an abundance of papers analyzing 
government measures that contribute to the business sector, as well as surveys on the influence of ICT on economic growth. At the same time, the literature on government measures in terms of incentives directed towards the ICT sector solely, are rare. Therefore, through this research the authors wanted to contribute to the theoretical discussion, as well as improve the current scientific knowledge about the influence of the government on the development of the ICT sector that is manifested through policies and implemented measures. In addition, the authors wanted to explore whether there is a link between company market orientation and the opinion of ICT experts on the development of different government ICT sector strengthening policies, with the aim of discovering if there is a need for developing specific and diverse government development strategies dependant on business market orientation. The research questions which were formed in this process are:

- What are the most important activities by which the government can influence the development of the ICT sector?

- Is there a difference in attitudes of the ICT experts depending on their affiliation to companies oriented on the foreign or domestic market?

The answers to the research questions developed through literature review. The authors conducted a survey with ICT experts with the aim of identifying important elements for supporting ICT businesses growth. The survey revealed the opinions of ICT experts on the role of government activities in the development of the Croatian ICT sector, and similarities in attitudes of companies oriented to the domestic and foreign market, which was not expected to be found in such an extent. Also, the association rule technique was used to uncover some interesting patterns.

This paper is structured through 5 chapters. The introductory chapter is followed by the review of recent literature on the topic of government policies and measures and their importance in fostering the ICT sector. The following chapters are methodology and research results. The last chapter consists of concluding remarks together with limitations of this research and suggestions for future research. The results of this research can be used in the preparation of future government strategies and policies for the ICT sector development where more precise measures need to be defined.

\section{Literature review}

\subsection{Fostering the EU and the national ICT sector development}

There are two basic benefits of incentivizing the ICT in the context of social welfare in developing countries: faster adaptation to modern technologies and benefiting from innovations [4]. Nevertheless, there is a fear that developing countries will not be able to use the benefits of the digital economy on an expected level, which will further widen the economic gap in comparison to developed countries $[9,10$, 11]. The reason can be found in their internal and external specificities and numerous challenges which can weaken the effects of policy implementation [12]. Here, government activities are of great importance for recognizing the best combination of policies and measures, as the same approach does not fit economies [13] where constant monitoring and modification is required [14, 15]. Per example, the Association of South-East Asian Nations made significant efforts to conduct and promote digital transformation and the ICT production sector. The measures were successful in the first period, but showed weaknesses and a need for redefinition in the following stages $[16,17,18]$.

In 2016, Sörvik and Kleibrink conducted a Mapping of EU investments in the ICT, where they found that a minimum of EUR 12.2 billion were invested in the core ICT. By including the results of core and non-core categories of interventions in ICT, this amount rises to EUR 21.4 billion. In a broader perspective, including e-Government, eHealth, digital content, digital skills, SME support, and Research and investment (R\&I), the investments in ICT would rise to EUR 35.5 billion [19]. This shows that EU recognizes that involvement and strategic investments are essential for the construction of infrastructure, digital transformation and strategic development of the ICT sector [20]. At the other side, only five EU member countries (Finland, Germany, Sweden, Malta and Austria) have succeeded to allocate all planned investments in the ICT for the period 2014 to 2020 through EU investment funds [21]. Unfortunately, in allocation and use of planned funds, Croatia is among the least successful countries, with only $38.08 \%$ allocated and $1.5 \%$ spent of the planned amount [21] where the low utilisation by ICT business [22] is not contributing to the improvement of the situation.

The $99.61 \%$ of 11,420 million EUR of EU funds which are directed through the thematic objective: Enhancing access to and use and quality of ICT are 
non-refundable grants, while the rest are supports through financial instruments and repayable grants [23]. But, it seems that there is a reluctance on the part of SMEs to embrace the e-businesses transformation models which are included in the ICT investment costs, as well as a lack of capacities and reluctance to network with other enterprises [3]. The proposed solution for this problem is the development of an eBusiness support framework by the EU states [24]. For the following programming period, EC proposed a new funding program with a total value of EUR 4 billion, primarily for dealing with online consumers' security issues and for SME's digital transformation [3]. To use these funds for strengthening absorption capacities, the interest of ICT companies and the government is essential.

The low demand for ICT products, lack of qualified workforce and insufficient government support lead to a slow development and slow adaptation of developing countries to the digital economy [25]. Although the Croatian sector shows a strong and stable growth, it seems that policy-makers do not understand the ICT sector's importance for overall economic growth, which is a situation comparable with neighbouring Serbia [26, 27]. The share of Croatian ICT in gross value added is 4.9\%; 7,399 companies and 45,128 employees [28]. When observing the IT sector, it can be seen that there is a trend for concentration reduction with an increase in the number of SMEs, with IT services companies as most represented by number of entities and employees $(44.4 \%$, $46.1 \%$ respectively), comparable with the EU level [29]. Oršić states that these results should contribute to making the governing structures understand that IT deserves their special attention in tax and regulatory terms [30]. Žitnik evaluated the dynamics of the current growth of the Croatian IT industry as too small, which is especially related to sales in the domestic market. In the period from 2015 to 2019 , IT sector sales in the country grew by an annual growth rate of $9.8 \%$, and export by $14.9 \%$, but still Croatia is growing slower than the rest of the $\mathbf{E U}$, where the EU28 gap index for 2018 is on the level of $45.2 \%$ [31]. The reason for that is, according to Žitnik, inadequate dynamic of digital transformation which is not ensuring a competitive position of the country in relation to the EU28 countries [32]. Although an investment support program exists, it seems that it does not generate planned investments. The Croatian Act on Investment Promotion in intended for domestic and foreign new investment projects in all sectors, including the investments in ICT development centres. The government is offering grants for project financ- ing, grants for R\&D, additional grant per every new employee as well as reductions of the corporate tax rate for up to 10 years, all in dependence of specific project characteristics [33, 34], but there are almost no other tax and regulatory incentives aimed specifically for the development of the ICT sector.

ICT investments support sustainable economic development of EU countries, and the government should make it a priority to increase their investments in improving infrastructure and connectivity and developing trainings for the use and development of ICT, as well as to ease access to ICT $[35,36]$. Of course, the balance should be kept, the government has a supportive role, without undermining the free market principles $[37,10]$.

\subsection{Government development measures}

In general, government development measures are introduced to stimulate economic and investment activity and growth, create jobs, and boost wages [38, 39, 40]. According to the EU: "state aid can be defined as an advantage given by a government that may provide a company with an unfair competitive edge over its commercial rivals. State aid can take several forms, such as public subsidies, tax relief, or the purchasing of goods and services on preferential terms" [40, p.1]. Incentives include state-budgeted program expenditures or tax expenditures. When tax reliefs are implemented through income taxation, systems are distinguished according to inputs (cost-oriented reductions) or by outputs (revenue-oriented reductions). Most important economic policies for the development of the business sectors are: Industrial policy, which shapes the industrial development through principles, policies, rules, regulations and procedures; Monetary policy, which aims to ensure enough financial resources to the enterprises and improves trade and industry; Foreign investment policy, with the aim of attracting investments with the purpose of accelerating industrial development, import of know-how and modern technologies [42].

Except EU programs, funds and guarantee schemes, EU member countries formulate activities on a national level (in the form of tax incentives, national grants and subsidies, guarantees etc.) for the actual European semester [43]. When analyzing EU member countries, the system in Estonia and Germany is based only on direct financial support, while all other observed member states have implemented some form of tax incentives, which is usually combined with direct aid. [44] Croatia mostly uses guarantees (around $45 \%$ of total state aid spending) and 
direct grant/interest rate subsidies, tax base reductions (33\% of total spending) [45].

While Cappelen and others argue that "EU regional support has a significant and positive impact on the growth performance of European regions" [46, p.621] there are some doubts on the efficiency of national level government incentives and policies [46, 38, 48, 49, 50]. Bergner and associates state that the government should build a simple tax system, business and legal environment, as a complicated system requires bigger administration [51, 47], which results in complex conditions and operational difficulties for businesses.

The usual taxation measures for investment support are tax reliefs and payment delays (holidays), but an increasing role in investment decision-making includes closing cross-border partnerships [52], contracts for avoiding double taxation and opening international markets. Tax incentives that provide "faster recovery of investment costs (e.g., investment allowances/tax credits and accelerated depreciation) are more cost-effective than those that involve reducing the corporate income tax (CIT) rates; CIT holidays are the worst among those in the latter category" [49, p. 1310]. However, this only applies to some countries as the impact of corporate taxation and other connected determinants on investments vary with the level of development [8]. Ivanov and associates state that "targeted" tools are more efficient as tax incentives can be used by those that are not able to use them effectively [38], which results in cost ineffective investments, [38, 49] which is more emphasized in developing countries. At the other side, Ohrn emphasizes that the government policies are directed towards larger and more liquid firms where they are using gained benefits to increase playouts and issue equity and therefore state measures have only a modest impact on investments [53]. Large projects and companies are more likely to get discretionary state subsidies, but there are mixed results analysis of spillover effects for the economy [39]. "Smaller, more financially constrained firms are more responsive to depreciation policies" [53, p. 299] and grants than on tax incentives. Therefore, the implementation of simple programs of tax reliefs is not sufficient. A more comprehensive economic-development strategy, with integrated financial and nonfinancial incentives and "targeted" tools to attract businesses to invest, are needed [38, 54].

Access to finances is especially important for SMEs in emerging economies and is identified in Yongzheng and Mao binding constraint for firm growth in developing countries [55]. Here the role of government subsidies and grants is of major importance. Although research show that there are difficulties in the utilisation of these funds because of lack of capacity in developing countries [46, 40, 56], still these resources are very useful and needed. It seems that "there is a strong relationship between government and entrepreneurship. This means that these two categories influence each other significantly" [51, p. 613]. Therefore, continuous measurement of efficiency and policy tuning is needed in order to develop an effective combination of legislative and administrative techniques [57].

\section{Methodology description and research results}

Since the emphasis of this research was set on exploring the attitudes of the target population of ICT experts (in this research the population of ICT experts was determined by the OECD and the Eurostat [58] definition of an ICT specialist), quantitative research was conducted and the non-probability convenience sampling technique was used. Data was collected by an anonymous questionnaire. The survey was conducted in the frame of a more comprehensive research which was conducted under the project "Economic significance and preconditions for the development of the IT sector".

The information obtained in 2019 from 112 ICT experts was used to create profiles of companies where they are employed, as well as to gather their opinions regarding the influence of the government on the ICT sector. The information included the main activity of the company, the state and the city where the company is registered, approximate calculation of the total revenues of the company in 2018, the size of the company, business orientation on the domestic or foreign market, estimated number of employees, as well as the role of the person who participated in this research in the company and their field of responsibility. Also, ICT experts' opinions on important government measures or activities were gathered. They were asked what government activities do they consider influential for the development of the ICT sector, if they think there is a strategic approach to the development of the IT industry in their country and do the government economic measures have an impact on the development of the ICT sector as well as to give their proposal in which segments should the government intensify its activity and measures to contribute to the growth of the ICT sector. Concerning the use of EU grants they expressed their opinion whether IT companies are reluctant to use 
grants from the EU and national grants and they gave the reasons why IT companies have so far underused them. Their opinion on the impact of clusters and professional associations on the development of the IT sector as well as which characteristics a stimulating business environment should have in order to achieve IT sector development was also examined.

Descriptive statistics, inferential statistics (chisquare test) and association rules as a data mining method were used to achieve the research goals using the software Statistica 13.

Regarding profiles of the companies whose employees participated in this research, the collected data show that the highest number of companies have main activities associated with computer programming (36.61\%), are mostly registered in Croatia (91.07\%) and the highest number of them were registered in Zagreb (42.86\%). The highest number of participants stated that (34.82\%) the company they are working for had total revenues more than 2,700,000 EUR for the observed year, is a medium size company (36.6\%) with more than 150 employees $(30.36 \%)$ and little more than a half of them $(56.25$ \%) were achieving sales on foreign markets. When it comes to profiles of the employees who participated in this research, the highest number of them (43.75\%) are working as a team member in their company with a field of responsibility connected with project management (44.64\%).

\section{Research results}

To investigate whether the orientation on domestic or foreign market is associated with their opinions regarding the government measures and involvement (variable labelled as orientation), the chi square measure was obtained. It revealed that there is a statistically significant association at the level of significance 0.05 between the developed international markets and the opinion of experts that the government should intensify its activities on agreements regarding avoidance of double taxation and regulation of cross-border data transmission $\left(\chi(1)=10.08, \mathrm{p}^{=} .0015\right)$, as well as not knowing the reasons why IT companies have so far underused financial resources and grants from EU or national funds and programs $(\chi(1)=7.27, \mathrm{p}=.007)$. Also, a statistically significant association at the level of significance 0.05 was discovered between the orientation on international markets and their opinion regarding the characteristic of a stimulating business environment in the form of less frequent changes in regulations $(\chi(1)=3.86, p=.049)$ and economic diplomacy which promotes the IT industry and mediates the creation and development of business relation$\operatorname{ships}\left(\chi(1)=5.50, \mathrm{p}^{=} .019\right)$.

As previously stated, the statistically significant association at the level of significance 0.05 was found between the variable developed international market and variables agreements, utilisation and stability. That is, the majority of experts from internationally and domestically oriented companies do not equally consider that signing agreements on avoidance of double taxation and regulation of cross-border data transmission $(93.9 \%, 69.8 \%$ respectively) and economic diplomacy that promotes the IT industry (79,6\% and $58.7 \%$ respectively) are not relevant activities for their development. On the other hand, $55.1 \%$ of domestic oriented companies consider that the stability of legislation (less frequent changes in regulations) is important economic activity, while internationally oriented companies in the majority (63.5\%) consider it unimportant. In general, the majority of all companies from the sample consider low taxation and minimal para-fiscal charges $(58.04 \%)$, as well as low level of administrative burdens and bureaucratization, characteristics of a stimulating business environment (71.43\%).

Additionally, the chi square measure was obtained to investigate sales on international markets. Other variables were used for the creation of company and employee profiles, and only 8 more variables with the $\mathrm{p}$ value smaller than 0.05 were used for generating association rules (see Table 1). The objective measures for selecting interesting rules were support, confidence and lift.

Altogether, 30 association rules were generated with a minimum support set to $50 \%$ (ranging from $50 \%$ to $100 \%$ ) and confidence to $50 \%$, and all of them had a lift value ranging from 1.01 to 1.08 .

The derived rules were sorted by multiple levels, that is, they were sorted by the highest support, then by the highest confidence and then by the highest lift. Rules with a support higher than $70 \%$ are presented in Table 2.

The most interesting rule from the rules presented in Table 1 is the first rule since it has the highest confidence (96.67\%), which means that it has a very high probability if the participant thinks that the reasons why ICT companies have so far underused financial resources and grants from EU and national funds and programs are known to him (utilisation = not unknown), the firm being registered in Croatia $($ state $=$ Croatia $)$. The size and the color of this rule node presented in Figure 1 indicates this, but it is also obvious that the location of the company's registration is influential and is present in many generated 
Table 1. CMMLF implementation cases. Source: Author's self-made

\begin{tabular}{|c|c|c|c|}
\hline Variable & Label & $\chi^{2}$ & $\mathrm{p}$ \\
\hline the place (city) where the company is registered & city & 21.45 & 0.00026 \\
\hline dominant activity of the company & activity & 10.92 & 0.00095 \\
\hline $\begin{array}{l}\text { signing agreements on avoidance of double taxation and regulation of cross-border } \\
\text { data transmission }\end{array}$ & agreements & 10.09 & 0.00149 \\
\hline state where the company is registered & state & 8.54 & 0.00347 \\
\hline \multicolumn{4}{|l|}{ the reasons why IT companies have so far underused } \\
\hline $\begin{array}{l}\text { financial resources and grants from EU and national funds and programs are } \\
\text { unknown }\end{array}$ & utilisation & 7.27 & 0.007 \\
\hline $\begin{array}{l}\text { economic diplomacy that promotes the IT industry and mediates the creation and } \\
\text { development of business relationships to achieve IT sector development }\end{array}$ & diplomacy & 5.50 & 0.01902 \\
\hline the role in the company & role & 4.40 & 0.03595 \\
\hline $\begin{array}{l}\text { the stability of legislation (less frequent changes in regulations) to achieve IT sector } \\
\text { development }\end{array}$ & stability & 3.86 & 0.04957 \\
\hline
\end{tabular}

Table 2. Rules with the highest support

\begin{tabular}{|c|c|c|c|c|c|}
\hline Rule & & & Support (\%) & Confidence (\%) & Lift \\
\hline Head & $==>$ & Body & & & \\
\hline utilisation= known & $=\Rightarrow$ & state $=$ Croatia & 77.68 & 96.67 & 1.06 \\
\hline state $=$ Croatia & $==>$ & utilisation $=$ known & 77.68 & 85.29 & 1.06 \\
\hline agreements=no & $==>$ & state $=$ Croatia & 73.21 & 91.11 & 1.00 \\
\hline state $=$ Croatia & $==>$ & agreements =no & 73.21 & 80.39 & 1.00 \\
\hline utilisation $=$ known & $==>$ & agreements =no & 65.18 & 81.11 & 1.01 \\
\hline agreements =no & $==>$ & utilisation = known & 65.18 & 81.11 & 1.01 \\
\hline
\end{tabular}

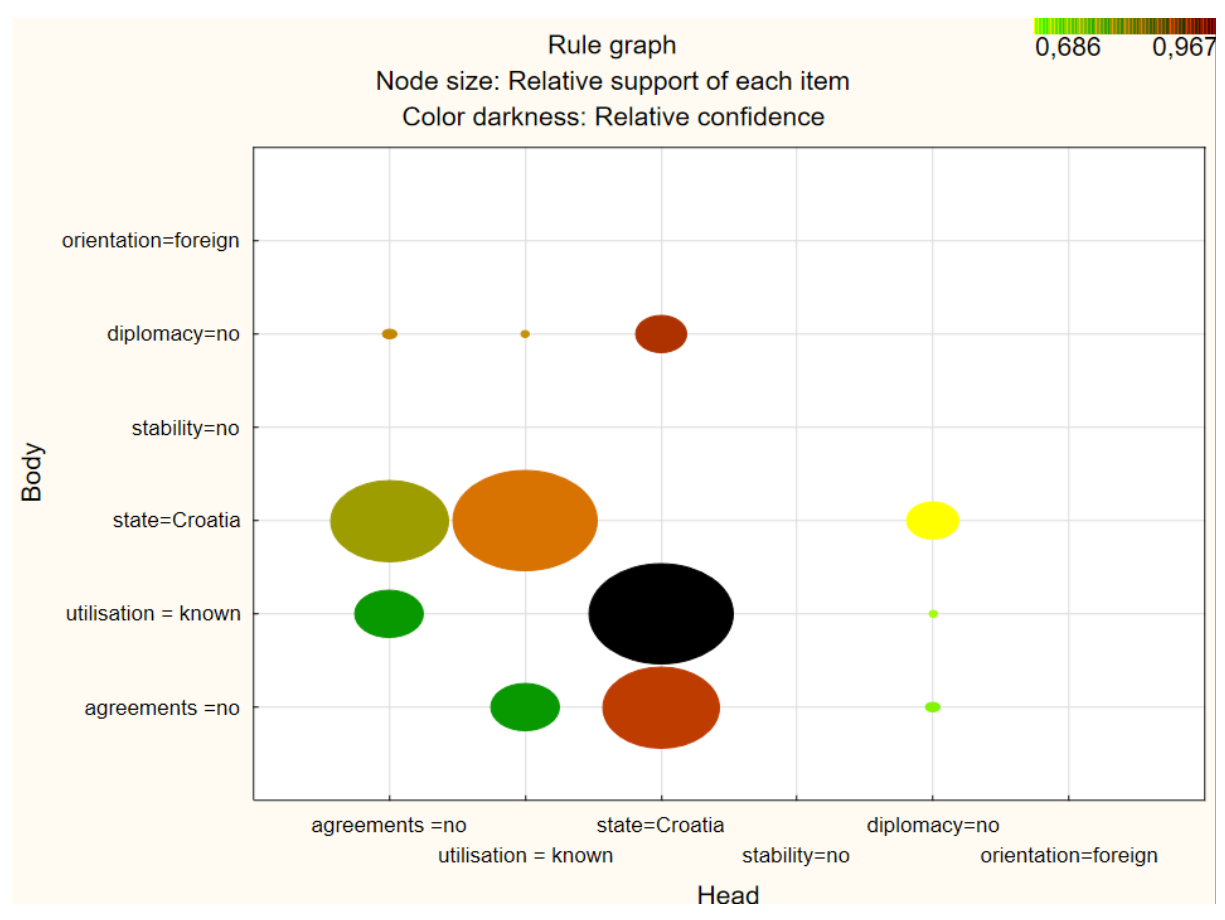

Figure 1. The rule graph of obtained rules 
rules due to its individual support. It can also be noticed from Table 2 that support and lift are symmetric measures, while confidence is not symmetric.

If only confidence is observed as a measure of interest, then the rule with the highest confidence (97.26\%) of all 30 derived rules is: if the participant stated that the government should not intensify its activities and measures in order to contribute to the growth of the ICT sector by signing agreements on avoidance of double taxation and regulation of cross-border data transmission then there is high probability that they also stated that the company is registered in Croatia. However, this rule does not have support higher than $70 \%$. The rules with the highest lift are presented in Table 3.

It is evident that when the highest lift is observed as a measure of significance for gaining rules, then the interesting rules have the same support (63.39\%). This can also be observed from line thickness of the rules presented in Figure 2. Since lift is a symmetrical measure, the first and second rule in Table 2. have the same value, but the confidence is higher in the second rule, therefore it is considered more interesting. It means that if a participant stated that the government should not intensify its activities and measures in order to contribute to the growth of the IT sector by signing agreements on avoidance of double taxation and regulation of cross-border data transmission then there is high probability that the participant stated that the reasons why IT companies have so far underused financial resources and grants from EU and national funds and programs data transmission are known to him.

\section{Conclusion}

The chosen models of government involvement and support of the ICT sector development depends on the government's understanding of the sector's importance on overall economic growth and its capaci-

Table 3. Rules with the highest lift

\begin{tabular}{|c|c|c|c|c|c|}
\hline Rule & & & Support (\%) & Confidence (\%) & Lift \\
\hline utilisation = known & $=\Rightarrow$ & agreements $=$ no & 63.39 & 78.89 & 1.08 \\
\hline agreements =no & $=\Rightarrow$ & utilisation =known & 63.39 & 86.59 & 1.08 \\
\hline agreements =no & $=\Rightarrow$ & state $=$ Croatia & 63.39 & 97.26 & 1.07 \\
\hline state $=$ Croatia & $=\Rightarrow$ & agreements =no & 63.39 & 69.61 & 1.07 \\
\hline
\end{tabular}

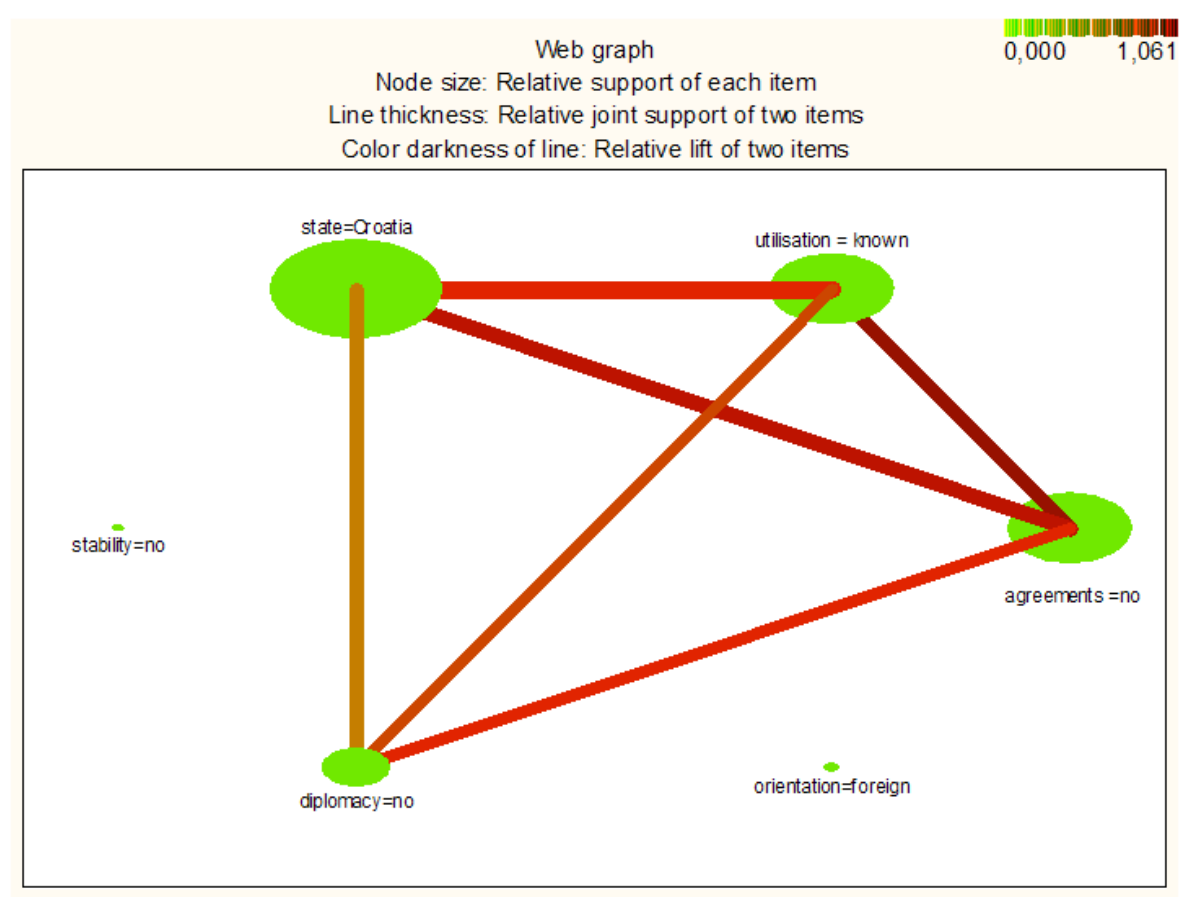

Figure 2. Graphical summary of obtained association rules 
ties to implement supporting measures and projects [46]. The authors of the research wanted to identify which economic measures do ICT experts perceive as important for the development of the ICT sector and to explore whether there is a need for introducing special development measures depending on international or domestic market orientation. Contrary to the authors' expectations, the results of the research show that there is a link between the companies' orientation on the domestic or foreign market and the opinion of ICT experts on the development of different government policies concerning the ICT sector. The statistically significant association was found between the variable developed international market and variables agreements, utilisation and stability. The majority of experts oriented towards both markets consider that signing agreements on avoidance of double taxation and regulation of cross-border data transmission and economic diplomacy that promotes the IT industry are irrelevant in fostering the ICT industry. The difference was found in the stability of regulations (less frequent changes in regulations) which experts from companies oriented on the domestic market consider important as opposed to those oriented towards foreign markets who did not rate this topic as relevant. The low taxation and minimal para-fiscal charges as well as a low level of bureaucratization are considered characteristic of a stimulating business environment by the majority of respondents.

The results lead to the conclusion that there is no need for the development of different policies for international and domestic oriented ICT companies, but the government should direct more attention to reducing administrative burdens and bureaucratization, as well as tax and parafiscal burdens placed upon companies. As well, frequent legal changes are an aggravating factor, especially for companies oriented towards the domestic market.

The limitations of the research are the sample size and geographical coverage as the majority of the respondents are regionally distributed. Also, this research does not analyze the specific government measures in different EU states which could be interesting for analyzing efficiency of government measures and the development of future development programs. Following, future research should include a more comprehensive survey on the regional or $\mathrm{EU}$ level with the aim of identifying regional specificities and identifying the examples of good practice.

\section{Acknowledgements}

The authors would like to thank the reviewers for their valuable suggestions. Also, authors would like to give special credit to the members and partners of the Osijek Software City association for supporting this research.

\section{Funding}

This paper is part of the Interdisciplinary research project "Economic significance and preconditions for the development of the IT sector", supported by the Josip Juraj Strossmayer University of Osijek [grant agreement number ZUP2018-33, 2018].

\section{References}

[1] Y. Vertakova, Y. Polozhentseva and M. Klevtsova, "Monitoring of the State and Dynamics of the Development of the Digitalization of the Industrial Economy," in International Scientific Conference "Far East Con" (ISCFEC 2018), Vladivostok, Russian Federation, published in Advances in Economics, Business and Management Research, vol. 47, pp. 1038-1041, 2019, doi: 10.2991/ iscfec-18.2019.71

[2] C. Zhang and X Wang, "The influence of ICT-driven innovation: a comparative study on national innovation efficiency between developed and emerging countries," Behaviour \& Information Technology, vol. 38, no. 9, pp. 876-886, 2019, doi: 10.1080/0144929X.2019.1584645.

[3] S. I. Cioacă, S. E. Cristache, M. Vuță, E. Marin and M. Vuță, "Assessing the Impact of ICT Sector on Sustainable Development in the European Union: An Empirical Analysis Using Panel Data," Sustainability, vol. 12, no. 2, p. 592, 2019, doi: 10.3390/su12020592.

[4] V. Kathuria, "Access and Investment in the ICT Sector for Developing Countries," Law and Development Review, vol. 9, no. 1, pp. 1-27, 2016, doi: 10.1515/ldr-2015-0013.

[5] R. Perez-Estebanez, E. Urquía-Grande and A. Rautiainen, "Technological and Economic Factors Determining ICT Level: Evidence from Rural Micro-Businesses in Democratic Republic of Congo," J. Int. Dev., Journal of International Development, vol. 29, No.8, pp. 118-133, 2017, doi: 10.1002/jid.3281.

[6] N. Hanna, "A role for the state in the digital age," Journal of Innovation and Entrepreneurship, vol.7, no. 5, pp. 2-16, 2018, doi: 10.1186/s13731-018-0086-3.

[7] European Commission, „Shaping Europe's digital future“. https://ec.europa.eu/info/strategy/priorities-2019-2024 /europe-fit-digital-age/shaping-europe-digital-future_en (accessed Feb. 1, 2021).

[8] A. Klemm and S. Van Parys, "Empirical evidence on the effects of tax incentives," International Tax and Public Finance., vol, 19, pp.393-423, June 2012, doi: 10.1007/ s10797-011-9194-8.

[9] P. Botolf Maurseth, “ ICT, Growth and Happiness,"in Digitalisation and Development Issues for India and Beyond, D. Maiti, F. Castellacci and A. Melchior, Eds. Singapore, Republic of Singapore: Springer Nature Singapore, pp. 31-86, 2020. doi: 10.1007/978-981-139996-1. 
[10] R. Hawash and G. Lang, "Does the digital gap matter? Estimating the impact of ICT on productivity in developing countries," Eurasian Economic Review,vol. 10, pp. 189-209, 2020, doi: 10.1007/s40822-019-00133-1.

[11] I. Bestvina Bukvić and I. Đurđević Babić, "Catching the IT Development Trends: What are the Odds?," in Megatrends And Media - Digital Universe. Smolence, Slovakia, 2019, pp. 34-54.

[12] M. I. Gariba. "Specific Tools of Regional Policy in Transforming Countries," Master Thesis, Faculty of Economics and Administration, University of Pardubice, Pardubice, Czech Republic, 2020. Available:https://dk.upce. cz/bitstream/handle/10195/75686/GaribaMI_Regional Development_MM_2020.pdf? sequence $=1$ \&isAllowed $=\mathbf{y}$ [Accessed: 22-Jul-2020].

[13] Y. Ai-Chi Loh and A. Chib, "Tackling social inequality in development: beyond access to appropriation of ICTs for employability," Information Technology for Development, pp. 1 - 20, Sep. 2018, doi: 10.1080/02681102.2018.1520190.

[14] O. A. Sinenko, "Methods of Assessing of Tax Incentives Effectiveness in Special Economic Zones: An Analytical Overview," Journal of Tax Reform, vol 2, no 3, pp. 168-178, 2016.

[15] N. Crato and P. Paruolo, The Power of Microdata: An Introduction in Data-Driven Policy Impact Evaluation:How Access to Microdata is Transforming Policy Design, N. Crato and P. Paruolo Eds.Cham, Switzerland:Springer Nature Switzerland AG, 2019, doi: 10.1007/978-3-31978461-8.

[16] K. M. Vu. "ICT diffusion and production in ASEAN countries: Patterns, performance, and policy directions,"Telecommunications Policy, vol. 41, no. 10, pp. 962-977, Nov. 2017, doi:10.1016/j.telpol.2017.04.005.

[17] P. Pholphirul and V. Bhatiasevi "IT investment and constraints in developing countries: Evidence from Thai manufacturers," Information Development, vol.32, no. 2, pp 186-202, 2016, doi: 10.1177/0266666914535616.

[18] K. Pitakdumrongkit, "Addressing Digital Protectionism in Asean: Towards Better Regional Governance in The Digital Age," Policy report, S. Rajaratnam School of International Studies, 2018. [Online]. Available:https://www.rsis.edu. sg/wp-content/uploads/2018/03/PR180321_AddressingDigital-Protectionism-in-ASEAN.pdf [Accessed: 19-Jul2020].

[19] J. Sörvik and A. Kleibrink, "Mapping EU investments in ICT - description of an online tool and initial observations," Publications Office of the European Union, Luxembourg, 2016, EUR 27983 EN, doi: 10.2791/963062. [Online]. Available:https://core.ac.uk/download/pdf/45616391.pdf. [Accessed: 20-Aug-2020].

[20] N. Bajpai, J. Biberman, and Y. Yingxin Ye, "National ICT-Driven Development Policy Comparing Approaches in India and China ICT India," Working Paper \#2, CSD Working Paper Series: Towards a New Indian Model of Information and Communications Technology-Led Growth and Development, Center for sustainable development, Earth Institute, Columbia University, Nov. 2018.

[21] European Commission, "European Structural and Investment Funds: Information \& Communication Technology,” 2021. [Online]. Available: https://cohesiondata .ec.europa.eu/themes/2. [Accessed: 20-Aug-2020].

[22] I. Bestvina Bukvil, "Impact of Business Environment on the Development of Regional IT Sector: Case of Eastern Croatia," in 7th International Scientific Symposium Economy of Eastern Croatia - Vision and Growth. Osijek, Croatia, 2018, pp. 719-727. Available: https://www.bib.irb. hr/976637/download/976637.Bestvina_Bukvic_ GIH_2018-2.pdf, [Accessed: 21-Aug-2020].

[23] European Commission, Smart Specialization Platform,
"ICT Monitoring - Planned ICT Investments under ESIF," 2017.Available:https://s3platform.jrc.ec.europa.eu/ictmonitoring. [Accessed: 20-Aug-2020].

[24] R. Gatautis, "TOWARDS eBUSINESS SUPPORT POLICY DEVELOPMENT: LITHUANIA PERSPECTIVES," Economics and Management, vol. 14, 2009, pp. 388-396, doi:10.5755/j01.em.0.14.9395.

[25] N. Kravchenko, S. Kuznetsova, A. Ivanova and A. Shemyakin, "Regional Aspects of Digital Economic Development," in Eurasian Economic Perspectives Proceedings of the 23rd Eurasia Business and Economics Society Conference, M. H. Bilgin, H. Danis, G. Karabulut and G. Gözgor Eds., 2020, pp. 265-277, doi: 10.1007/9783-030-40375-1_19.

[26] I. Domazet, J. Zubović and M. Lazić, "Driving Factors of Serbian Competitiveness - Digital Economy and ICT," Strategic Management -International Journal of Strategic Management and Decision Support Systems in Strategic Management, vol. 23, no.1, 2018, pp. 20-28, doi: 10.5937/ StraMan1801020D.

[27] A. Kleibrink, N. Radovanovic, H. Kroll, D. Horvat, D. Kutlaca, D. and L. Zivkovic, "The Potential of ICT in Serbia: An Emerging Industry in the European Context," Publications Office of the European Union, Luxembourg, 2018, EUR 29558 EN, doi:10.2760/994464, JRC114209. Available:https://ec.europa.eu/jrc/en/publication/ potential-ict-serbia-emerging-industry-european-context [Accessed: 22-Jul-2020].

[28] Ministry of Economy, Entrepreneurship and Crafts, "Invest in ICT in Croatia." [Online]. Available: http://investcroatia. gov.hr/wp-content/uploads/2018/11/AIK_ICTinvest_ web-1.pdf. [Accessed: 22-Jul-2020].

[29] European Commission, "Digital Economy and Society Index 2020, The EU ICT Sector and its R\&D Performance." [Online].Available: https:/ec.europa.eu/ newsroom/dae/document.cfm?doc_id=67083. [Accessed: 21-Aug-2020].

[30] E. Oršić, "CISEx u brojkama: rezultati članica za 2019. i očekivanja za 2020. godinu,” Croatian Independent Software Exporters,Cisex.org.[Online]. Available: https:// www.cisex.org/hr/blog/cisex-u-brojkama-rezultati-clanicaza-2019-i-ocekivanja-za-2020-godinu. [Accessed: 22-Aug2020].

[31] B. Žitnik, D. Subotičanec, "Analiza hrvatske IT industrije 2014. - 2019, "Zagreb, Hrvatska, Hrvatska gospodarska komora, Dec. 2020.

[32] B. Žitnik, "Analiza hrvatske IT industrije 2008. - 2017, "Zagreb, Hrvatska, Hrvatska gospodarska komora, Nov. 2018. [Online]. Available:https://www.hgk.hr/documents/ analizahrvatskeitindustrije 5c372c1f59ebb.pdf. [Accessed:22Jul-2020].

[33] Agency for investments and Competitiveness, Republic of Croatia, "Best cost destination: Invest in ICT in Croatia." [Online]. Available: http://investcroatia.gov.hr/wp-content/ uploads/2018/11/AIK_ICTinvest_web-1.pdf. [Accessed: 22-Aug-2020].

[34] Ministry of Economy and Sustainable Development of Republic of Croatia. "Incentive measures for investment projects.” Available: http:/investcroatia.gov.hr/en/ incentives/incentive-measures-for-investment-projects/. [Accessed: 21-Aug-2020].

[35] A. Fernández-Portillo, M. Almodóvar-González, J. L. Coca-Pérez and H. V. Jiménez-Naranjo, "Is Sustainable Economic Development Possible Thanks to the Deployment of ICT?,” Sustainability, vol.11, no. 22, p. 6307 (pp. 1-15), 2019; doi:10.3390/su11226307.

[36] E. Toader, B. N. Firtescu, A. Roman and S. G. Anton, "Impact of Information and Communication Technology Infrastructure on Economic Growth: An Empirical 
Assessment for the EU Countries," Sustainability, vol.10, p. 3750 (pp. 1-22), 2018, doi: 10.3390/su10103750.

[37] D. Kapur, "Why Does the Indian State Both Fail and Succeed?, Journal of Economic Perspectives , vol. 34, no. 1, 2020, pp. 31-54, doi: 10.1257/jep.34.1.31.

[38] V. V. Ivanov, N. A. Lvova, N. V. Pokrovskaia and S. V. Naumenkova, "Determinants of tax incentives for investment activity of enterprises," Journal of Tax Reform, vol. 4, no. 2, pp. 125-141, 2017, doi: 10.15826/jtr.2018. 4.2.048.

[39] C. Slattery and O. Zidar, "Evaluating State and Local Business Incentives," Journal of Economic Perspectives, vol 34, no. 2, pp. 90-118, 2020, doi: 10.1257/jep.34.2.90.

[40] R. Hassink and H. Gong, "Six critical questions about smart specialization,” European Planning Studies, vol. 27, no.10, pp. 2049-2065, 2019, doi: 10.1080/09654313.2019.1650898.

[41] C. Karakas, C. Stamegna and I. Zachariadis, "Public economic support in the EU: State aid and special economic zones," European Parliamentary Research Service, Briefing PE 646.164, Feb. 2020. Accessed: Jan. 7, 2021. [Online]. Available: https:/www.europarl.europa.eu/thinktank/en/ document.html?reference=EPRS_BRI(2020)646164

[42] H. Vedamani, "Business Environment - Conceptual Framework and Policies," International Educational Scientific Research Journal, vol. 4, no. 3, pp. 67-74, Mar. 2018. Accessed: Jan. 28, 2021.

[43] K. Jurlin, V. Samardžija and M. Basarac Sertić, "Konkurentnost, pametna specijalizacija i investicije u novim državama članicama EU-a i Hrvatskoj," Institut za razvoj i međunarodne odnose (IRMO), Zagreb, Croatia, POLO-Cro28 Policy Paper, 2018. Accessed: Jan. 21, 2021. [Online]. Available: https://irmo.hr/wp-content/ uploads/2020/03/Polo-PP-Konkurentnost-27-2.pdf

[44] N. Šimurina and B. Galić, "Usporedna analiza poreznih poticaja za istraživanje i razvoj u Europskoj uniji," Zbornik Ekonomskog fakulteta u Zagrebu, vol. 15, no. 2., 2017, pp. 105-126.

[45] European Commission, DG Competition. Policy and Strategy State aid, Policy and Strategy. State aid Scoreboard 2019. [Online]. Available: https://ec.europa.eu/competition/ state_aid/scoreboard/state_aid_scoreboard_2019.pdf

[46] A. Cappelen, F. Castellacci, J. Fagerberg and B. Verspagen, "The Impact of EU Regional Support on Growth and Convergence in the European Union." Journal of Common Market Studies, vol. 41, no. 4, 2003, pp. 621-44, doi: 10.1111/1468-5965.00438.

[47] S. M. Bergner, R. Bräutigam, M. T. Evers and C. Spengel. "The Use of SME Tax Incentives in the European Union," Zentrum für Europäische Wirtschaftsforschung, Discussion Paper No. 17-006, Jan. 2017. Accessed: Jan. 5, 2021. [Online]. Available: http://ftp.zew.de/pub/zew-docs/dp/dp17 006.pdf

[48] I. Bestvina Bukvić, M. Basarac Sertić and M. Harc "Economic impact of government measures: Analysis of the construction sector," in 8th International Scientific Symposium Economy of Eastern Croatia - Vision And Growth, Osijek, Croatia, 2019, pp. 260-277.

[49] H. Zee, J. G. Stotsky and E. Ley, "Tax Incentives for Business Investment: A Primer for Policy Makers in Developing Countries." World Development, vol. 30, no. 9, 2002, pp. 1497-1516.

[50] J. Lerner, "Government Incentives for Entrepreneurship," National Bureau of Economic Research, NBER Working paper series, Working Paper 26884, Mar. 2020, Accessed: Jan. 5, 2021. [Online]. Available: http://www. nber.org/papers/w26884

[51] M. Ziolo and M. Ben Ghoul, "The role of the government in enhancing sustainable entrepreneurships," International
Journal of Business and Globalisation, vol. 22, no. 4, 2019, pp. 595-617, doi:10.1504/IJBG.2019.10021972.

[52] O. Sinenko and I. Mayburov, "Comparative Analysis of Tax Incentives in Special Economic Zones in the Countries of the Asia-Pacific Region," in 11th International Days of Statistics and Economics, † Prague, Czech Republic, 2017, pp. 1421-1430.

[53] E. Ohrn, "The Effect of Corporate Taxation on Investment and Financial Policy: Evidence from the DPAD” American Economic Journal: Economic Policy, vol. 10, no. 2, May 2018, pp. 272-301, doi: 10.1257/pol.20150378.

[54] C. Gonzales, M. Kerlin, R. Schaff and S. Tucker-Ray," How state and local governments win at attracting companies.” McKinsey \& Company. https://www.mckinsey. com/industries/public-and-social-sector/our-insights/howstate-and-local-governments-win-at-attracting-companies\# (accessed Feb. 1, 2009).

[55] L. Yongzheng and J. Mao, "How Do Tax Incentives Affect Investment and Productivity? Firm-Level Evidence from China." American Economic Journal: Economic Policy., vol. 11, no. 3, 2019, pp. 261-91, doi: 10.1257/pol.20170478.

[56] M. I. Gariba, "Specific Tools of Regional Policy in Transforming Countries,” M.S. thesis, Faculty of Economics and Administration, University of Pardubice, Czech Republic, 2020. Accessed: Dec. 21, 2021. [Online]. Available:https://dk.upce.cz/bitstream/handle/10195/ 75686/GaribaMI_RegionalDevelopment_MM_2020. pdf? sequence $=1 \&$ isAllowed $=\mathrm{y}$

[57] S. S. Surrey, "Tax Incentives as a Device for Implementing Government Policy: A Comparison with Direct Government Expenditures," Harvard Law Review, vol. 83, no. 4, Feb. 1970, pp. 705-738.

[58] Eurostat, ICT specialists in employment, 2020. https://ec. europa.eu/eurostat/cache/metadata/en/isoc_skslf_esms.htm (accessed Feb. 1, 2021). 